\title{
Internet Usage and Its Impact on The Academic Writing Performance of EFL Student at Tertiary Level
}

\author{
Dzul Rachman ${ }^{1}$, Dedi Rahman Nur ${ }^{2}$, and Arbain ${ }^{3}$ \\ \{dedi@yahoo.com ${ }^{2}$ \} \\ ${ }^{1}$ Universitas Muhammadiyah Kalimantan Timur, Samarinda, Indonesia \\ ${ }^{2,3}$ Universitas Widya Gama Mahakam
}

\begin{abstract}
As it is recognized that numerous information provided by internet recommendation in term of gaining academic assignment, creating a draft by using internet as reference to gain some information and other stuffs linkage by the internet as sophisticated media recently. Almost of user included worker, students, researcher or instructor, etc. apply this media to run their interest. This investigation undertaken to identify the linkage between internet usage and writing performance particularly for academic writing among student at tertiary level. The purpose of this research was to determine whether internet action was recommended for doing the writing assignment. This research conducted by applying correlational study. Researcher retrieved the data based on the internet recommendation samples and case assignment which has similar idea from the assignment given among tertiary student. The sample was randomly from undergraduate's institution of East Kalimantan. From the results of r-final calculation, internet usage contributed positive development, and this research had a good interrelationship. Internet could be a device for improving the undergraduate student to produce and increase their working since it help the quality of writing. In another concept, the result can be explained that by internet practicing as resources increase numerous benefits in giving sources, references, sample and assist to develop the idea related to writing assignment.
\end{abstract}

Keywords: Academic Writing, English Foreign Language, Tertiary Level, Internet

\section{Introduction}

The world is celebrating the improvements in communication technology which has broadened the scope of communication through Information and Communication Technologies [1]. Improvements in information and communication technology tied the world closer. Internet has experienced extraordinary growth in both its size and number of users around the world [2]. On the other hand, as English is a popular language currently, it is being taught according to needs of the students. Among these skills, Kroll [3] points out the importance of writing skill, and emphasizes that writing is the hardest one to get success when compared with other skills like reading, comprehending and speaking.

Many suggestions have been drawn to find the ways to teach writing. Producing a successful piece of writing can be accomplished on condition that one has a concurrent control in language systems [3]. In addition to teaching through form, Warschauer [4] also highlights that computers can be used to teach new types of writing considering the online age that we 
live in today. Warschauer [5] states that new technologies can help us teaching writing in second language.

Considering the importance of form, vocabulary and grammar in developing writing skill, the present study combines these language areas with technology. The research questions of the study are any relationship between internet usage and writing performance of undergraduate of University?

\section{Method}

The design of this research is correlation design. The purpose of the design is to examine the relationship of one variable to the other one. The first variable under study is the score of internet usage and the second variable is the score of writing performance. Mertler [6] point out that Correlational research in education seeks out traits, abilities, or conditions that covary, or co-relate, with each other.

Cresswell [7] population is a group of individuals who have the same characteristics. Considering about these explanations the sample of this research was the fifth semester of English Department. The participants of the present study are 50 undergraduates. Their level is $\mathrm{B} 2$, and their age ranges from 18 to 24 . All of the participants are voluntary to participate in the present study.

For the first tool, the questionnaire was used to obtain the data on internet usage. The questionnaire was adopted from 'Pengaruh Internet Dalam Pembelajaran Jarak Jauh (ELearning)' by Hapsari [8] and 'Penggunaan Internet oleh Mahasiswa terhadap Tingkat Minat Baca Mahasiswa' by Abdurrahman [9]. Scoring item in the questionnaire, the writer used Likert scale (five scales). Lastly, as the second data collection tool, the researcher used written test, which is Writing essay test. In scoring the students' test, the researcher involved two scorers. They had graduated in English Department, trustworthy, responsible, and they are an English teacher.

There are two kinds of data that were used for this study, namely data on internet usage and data on writing performance. Data were collected based on the following procedures before analyzing by Product Moment Formula to see the correlation of the first variable (Internet usage) to the second variable (scores on writing performance).

The data of Internet usage were obtained from questionnaire. Data on Internet usage were given after the writer distributed the questionnaire. The answer of the questionnaire is scored by the researcher, and then the writer tabulated the scores on questionnaire. The data of writing performance is obtained from the scores of argumentative writing at the fifth semester students of University.

\section{Result \& Discussion}

The findings were presented to describe the results of analysis on the operation of the rtest formula and hypothesis testing. The comparison between r-value and r-table used in this study indicated that $r$-value was higher than $r$ table $(0.839>0.297)$. This meant that Ho was rejected and the study was significant. The study revealed that internet usage related to writing performance of the fifth semester student of Mulawarman University. 
Table 1. Correlations.

\begin{tabular}{rlrr}
\hline & & $\mathrm{x}$ & \multicolumn{1}{c}{$\mathrm{y}$} \\
\hline $\mathrm{x}$ & Pearson Correlation & 1 & .839 \\
& Sig. (2-tailed) & & .060 \\
& N & 50 & 50 \\
$\mathrm{y}$ & Pearson Correlation & .839 & 1 \\
& Sig. (2-tailed) & .060 & \\
& N & 50 & 50 \\
\hline
\end{tabular}

Based on the result of the hypothesis testing above, an interpretation was made that internet usage had high correlation with writing performance. In other word, the more students use internet, the better result they got in writing performance. In addition, internet bring many advantages to do writing, internet gives the easy way to get the information quickly. On the other hand, a lot of information provided by the internet makes students have no initiative to create and develop their own writing. Therefore, some students do writing by copying the material from the internet.

The internet facilities bring many advantages in education especially in writing activity. The Internet and computers provide many facilities at home and work place as anyone can share his experiences and thoughts with the entire world through blogs, Wikis and web-sites. According to Ashish [10], learners of this new generation have no boundaries at all, they can find the information about anything while sitting in their living rooms by goggling it through their mobiles which are connected to the internet. In the writing activities usually students are asked to write paragraphs and essays. Before they write, students need many sources to read in order to have a good and well-informed writing. The researcher believes, somehow, internet can help writers as it encompasses many different ways of communicating and exchanging information.

The discussion in this study was focused on two areas of concerns. First, the discussion was presented to give comments on internet usage in writing performance. The result on internet usage showed that the students of a sample received high average score with 66. Second, the discussion was focused on scores of writing performance.

From the data of internet usage, it was showed that the participants have high internet usage. It meant that the students use the internet to do writing. In addition, students use the internet facility as a tool to help them to finish their writing. Schrater [11] found that students with access to any of a number of technologies (such as computer assisted instruction, integrated learning system, simulations and software that teaches higher order thinking, collaborative network technologies.) show positive gains in achievement. Students that got high score in their writing showed that the internet usage had correlation on writing. However, some students still do not have correlation between internet usage and writing. It shows by the score of their writing assignment. Some students get high score in questionnaire but got the low score in writing. That was happened because they cannot elaborate and utilize the information provided by internet or they did not answer questionnaire seriously.

Data of scores of writing performance is good with the average score 72.6. It indicated that the student had good performance in doing writing and had less of difficulty in their writing. Students can improve their writing assignment by using internet. According to Mohamed \& Ayeche [12] students can learn from the internet use to increase basic skill and knowledge, and can use information technology for a variety of goal in the learning process and can serve as a resource to help them develop their writing performance. Besides, the can got the material of writing assignment faster than in the library to save time and costs. 
The result of data analysis using Product Moment Formula showed that the result is significant. It can be seen from the result of calculation by Product Moment Formula that achieved the correlation coefficient 0.839 . It meant that the usage of the internet by students had high correlation to their writing performance. So, the researcher concluded that students who use the internet frequently can get the better result on their writing performance.

\section{References}

[1] Asemah, E.S. Okpanachi, R.A. and Edegoh, L.O.N. Influence of Social Media ot the Academic Performance of the Undergraduate Students of Kogi State University, Anyigba, Nigeria, Research on Humanities and Social Sciences, Vol. 3(12), pp. 90-96 (2013).

[2] Usman, N.H., Alavi, M. and Shafeq, S.M. Relationship between Internet Addiction and Academic Performance among Foreign Undergaraduate Students. Procedia- Social and Behavioral Sciences, Vol. 114, pp. 945-851. (2014).

[3] Kroll, B. in M. Celce-Murcia (Eds.) Teaching English as a second or foreign language (pp. 233248). Heinle \& Heinle Boston (2001).

[4] Warschauer, M. Technology and writing. In C. Davison \& J. Cummins (Eds.) The International Handbook of English Language Teaching (pp. 907- 912). Springer. Norwell, MA (2007).

[5] Warschauer, M. Invited commentary: New tools for teaching writing. Language Learning \& Technology, 14 (1), 3-8 (2010).

[6] Mertler, Craig A. Introduction to Educational Research. 2nd edn. Sage Publications, Inc., Los Angeles (2009).

[7] Creswell, John W. Educational research : planning, conducting, and evaluating quantitative and qualitative research. 4th edn. Pearson Education Inc., Boston, MA (2012)

[8] Hapsari, Likhu Puspa. Pengaruh Penggunaan Internet dalam Pembelajaran Jarak Jauh (E-Learning) terhadap Efektivitas Pengajaran Bahasa Indonesia kepada Penutur Asing. ASILE 2014 Conference. (2014).

[9] Ashish Paliwal, Lajwanti. The Impact of Internet use on Study Habits of Higher Secondary Students. Journal of Education and Practice, 3(15), 94-100 (2012)

[10] Schacter, J. The impact of Educational Technology on Student Achievement: What the most current research has to say. Milken Exchange on Educational Technology, Santa Monica, CA. (ERIC Document Reproduction Service No. ED 430537 (1999)

[11] Ayeche, Ziyad. and Muhammed Khanchali, The Impact of the Internet on the Deveopment of Students' Writing. Batna University: Revue des Sciences Humaines - Université Mohamed KhiderBiskra No: 21 (2011) 